\title{
William Walker James Nicol, D.Sc.
}

W. W. J. Nicol was born in Edinburgh in 1855, and died there on 18th March 1929. He was educated first in England and later at Edinburgh Academy, where he was in the same class as Lord Haldane. He entered the University of Edinburgh in 1872, took his M.A., then becoming attracted by Chemistry, gained the medal of his year, also the Hope Prize Scholarship, and later the degrees of B.Sc. and D.Sc.

A survey of Dr Nicol's career shows that he was a born teacher, and also as Pattison Muir said, "a careful and very original investigator." For a time he did research in Hofmann's laboratory in Berlin. His first experience in teaching came as demonstrator in the Edinburgh University laboratory. From there, in 1876, he was asked by Professor Letts to go as Lecturer in Chemistry to University College, Bristol, and four years later was appointed to the Lectureship in Chemistry at Mason College, Birmingham, now University, where he remained until 1894.

By his advanced students in Birmingham he was regarded as a genius. One of them remembers that "if you want to have anything explained, go to Dr Nicol," was a common piece of advice. The fact that he was repeatedly called upon to give popular lectures, and many courses of lectures, in various towns in the south and west of England points to his success as a teacher. His mind was full of ideas which he worked out only far enough to satisfy himself as to their truth. For him, teaching and research fertilised each other, and this partly accounts for the fact that when he retired from teaching he gradually gave up research.

At the period of his special chemical activity, from 1882 until 1898, the interest of many other investigators was mainly centred in the chemistry of the carbon compounds, and physical chemistry, which is now in the forefront, was hardly born. Dr Nicol, in devoting himself principally to solving difficult physico-chemical problems, such as those connected with the phenomena of solution, was really in advance of his time; his work therefore met with comparatively little recognition in his own country. Ostwald, Mendeleeff, Menshutkin, Kopp, and Berthelot, however, saw its value, and expresser their opinion as to the accuracy, clearness of insight, and originality of his investigations. His results were embodied in numerous papers contributed chiefly to this Society, to the London Chemical Society, to the Philosophical Magazine, and to various chemical

P.R.S.E.-VOL. XLIX. 
journals here and in Germany. They dealt with such subjects as solution, saturation, super-saturation, coefficient of expansion, molecular volumes, vapour pressures, water of crystallisation, and with microscopic observation of the allotropic forms of many salts, as they crystallised out under varying conditions of temperature and pressure. Possessing a highly ingenious and versatile mind, as well as singularly skilful hands, Dr Nicol passed from pure research and the contrivance of chemical apparatus, from expert glass-blowing and photography, to all sorts of work in wood and metal, and to motor engineering. His mind was ever full of invention, and his power of quick observation enabled his hands to carry out his thought intuitively without any outside aid or teaching, so that he made with perfect finish and ease whatever he wished in his fully equipped workshop and laboratory.

The chief enjoyment ef his leisure was caravaning, to which was added the special zest of building entirely with his own hands various types of caravan, fitted with every sort of contrivance for comfort and 'convenience.

Dr Nicol was quiet and reserved; he enjoyed meeting friends in his own house, but was not overmuch inclined to go into society or to attend meetings. What perhaps most impressed those who knew him intimately was his unfailing gentleness and courtesy, which, together with a strong sense of humour, made them feel him to be one of the most lovable of men.

Dr Nicol was elected a Fellow of the Society in 1880.

L. D. 